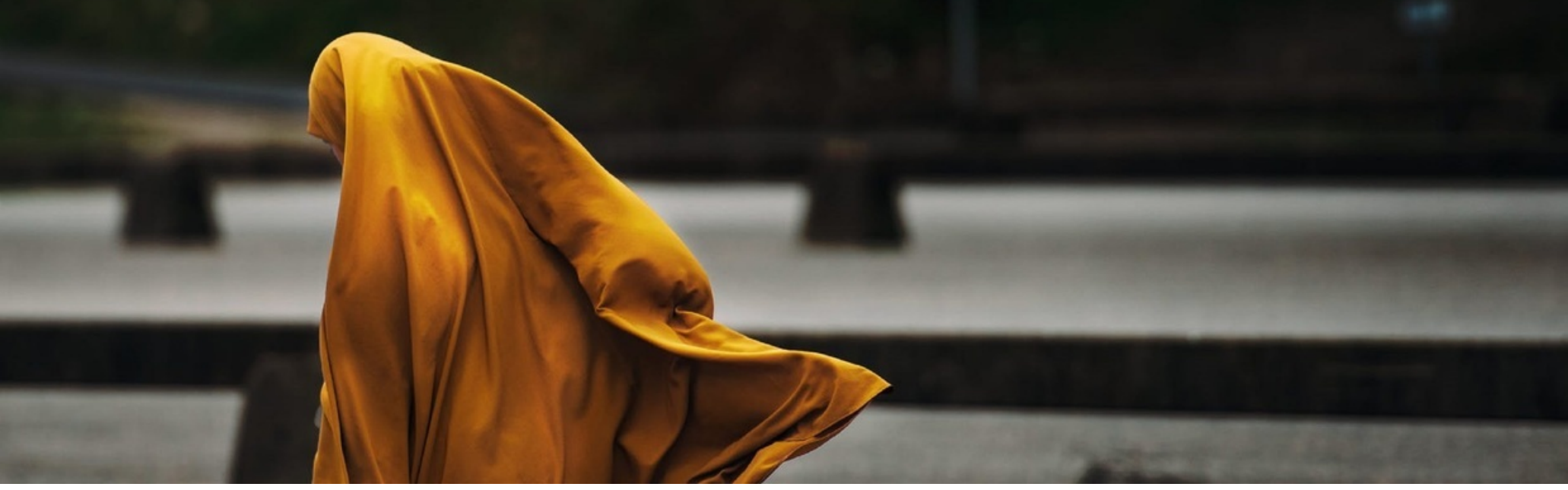

\title{
Moving Beyond Home: The Changing Status of Muslim Women in Northern Nigeria.
}

\author{
Authors: Usman Al-amin \\ Submitted: $\quad$ 10. November 2018 \\ Published: $\quad$ 13. November 2018 \\ Volume: 5 \\ Issue: $\quad 9$ \\ Affiliation: Department of History. University of Maiduguri. Borno State, \\ Nigeria \\ Languages: English \\ Keywords: $\quad$ Nigeria, History, Religion, Women \\ Categories: Humanities, Social Sciences and Law \\ DOI: $\quad 10.17160 /$ josha.5.9.502
}

\section{Abstract:}

The relationship between the religions, customs, and status of women across the world is an enduring global mystery. In northern Nigeria, several years ago, Muslim women remain disadvantaged in many areas of life, including education, employment, health, and civil rights. Gradually, some of the changes appeared in the picture which have greatly improved the lives and status of women in the region, particularly the social, economic and political status. The northern Nigerian Muslim women have switched over from the backstage to the forward. Hence, in northern Nigeria today, we have women in virtually all spheres of life. A lot has been said about the status of women in northern Nigeria, however, so far, most research was limited to general introduction or explanations to the single facts, such as polygyny, divorce etc. This research-which I consider a pilot study is a description of the changing status of Muslim women in northern Nigeria. 


\title{
Moving Beyond Home: The Changing Status of Muslim Women in Northern Nigeria
}

Usman Al-amin

Department of History, University of Maiduguri. Borno State, Nigeria. alaminusman81@gmail.com

\begin{abstract}
The relationship between the religions, customs, and status of women across the world is an enduring global mystery. In northern Nigeria, several years ago, Muslim women remain disadvantaged in many areas of life, including education, employment, health, and civil rights. Gradually, some of the changes appeared in the picture which has greatly improved the lives and status of women in the region, particularly the social, economic and political status. The northern Nigerian Muslim women have switched over from the backstage to the forward. Hence, in northern Nigeria today, we have women in virtually all spheres of life. A lot has been said about the status of women in northern Nigeria, however, so far, most research was limited to general introduction or explanations to the single facts, such as polygyny, divorce etc. This research-which I consider a pilot study is a description of the changing status of Muslim women in northern Nigeria.
\end{abstract}




\section{Introduction}

Throughout human history, woman's status has been considered as inferior to that of man. All religious (apart from Islam) ${ }^{1}$ accorded her inferior status "ranging from absolute dependence on man, non-legality and even sub-humanity. Even in Islamic societies across the world, Islam and customs, coupled with the conditions in which the women had lived in community, greatly influenced their status and position. In northern Nigeria, the lengthy existence under the realm of tradition with varied degrees of obnoxious practices which relegated the women to a second sex. ${ }^{2}$ The woman is considered as the back bencher in all spheres of human endeavor, ranging from social, economic to political participation. ${ }^{3}$ These restrictions are meant to make the women retain their status as not to compete favorably with the menfolk. The status of women in the region relegated to the background and unless something is done to improve it, the impoverished situation would not allow women to rise to the challenge. ${ }^{4}$ By the end of the nineteenth century, the societies of the northern Nigeria, along with other members of the world community, had witnessed farreaching changes triggered by political, economic, social, and cultural developments. ${ }^{5}$ Today, among the northern Nigerian Muslim women, there are outstanding political leaders who have positioned themselves strategically in national life. ${ }^{6}$ In the civil service too, there are northern Nigerian Muslim women who are performing wonderfully, exampled by the fact that currently heading the federal and state civil services. ${ }^{7}$ In academic too, northern Nigerian Muslim women are impacting seriously, as well as in all other areas of human endeavor like sports and journalism. ${ }^{8}$ This study focuses on those factors and changes influencing Muslim women in northern Nigeria during the nineteenth and twentieth century until the mass involving of Muslim women in politics and socio-economic spheres in the beginning of the twentieth first century. It examines how

\footnotetext{
${ }^{1}$ Ibrahim N. Sada 1988:27-8.

${ }^{2}$ Uwa Lohor 1998:37.

${ }^{3}$ Ibid.

${ }^{4}$ Ibid 39.

${ }^{5}$ Ben Orewere 1998:21.

${ }^{6}$ S.R. Janfa 1998:14.

7 Paulin Tare Shagaya 1998:10.

8 Ibid.
} 
changes in Nigerian society affected Nigerian Muslim women and analyze the developments in their status, family life, work, education, and participation in public life. It also examines how the developments in each of these spheres influenced one another and how changes were woven into the national way of life and thought. The study submitted that the colonialism, education, women organizations, and movements as well as changing political leadership presented the Nigerian Muslim women with different models of social and cultural behavior. These changes in the foci of inspiration and imitation had significant implications for the status and position of Nigerian Muslim women, as Islamic traditional society was exposed to modernizing and westernizing influences.

\section{Northern Nigeria: Space and Time}

There are many excellent books on the origin, extent, organization, and history of northern Nigeria already in print. This introductory note has been written to help the absolute newcomer to West African social history. Although the term "Northern Nigeria" no longer has any official use and somewhat outdated now, it is currently used to describe an area which was a British protectorate that lasted from 1900 until 1914 and covered the northern part of what is now Nigeria. The protectorate spanned 660,000 square kilometers (255,000 sq. mi) and included the states of the Sokoto Caliphate and parts of the former Bornu Empire, conquered in 1902. ${ }^{9}$ The area where is now known as Northern Nigeria, remains "abstract" to those in the south and the international community, as very little is known about the region regarding the status and roles of Muslim women. The entity known as northern Nigeria is a marriage of many cultures and traditions, but Islamic cultures had been entrenched in present northern Nigeria. The main Islamization of the northern Nigeria took place by way of the Borno Caliphate, Kano and down to the Katsina, people are Islamized but kept their own language and some elements of their culture. In fact, Islam had spread to the south and Tiv region of the middle belt were completely sealed off from the light of Islam. ${ }^{10}$ Since the arrival of Islam in the region, Northern Nigeria has experienced the rule of various regimes, which have differed as to their origin, religion, overall policies, and attitude

\footnotetext{
9“Northern Nigeria” Wikipedia, accessed on 13.09.2018.

${ }^{10}$ Latifa Okunnu 1988:85
} 
toward the population at large and toward the women. These different outlooks affected relations between the man and the authorities and the society. This, in turn, also influenced the status and position of women.

\section{Contextualizing Northern Nigerian Muslim Women}

Before specifically discussing the status of Muslim women in northern Nigeria, it may be useful to contextualize northern Nigerian Muslim women. The term is used to refer to mainly Muslim women living in the northern part of Nigeria, specifically Hausa, Kanuri, Fulani, who constitute the largest and most influential ethnic groups in the region. Northern Nigeria being the dominant Islamic and patrilineal, multi-ethnic, satisfied, and dynamic society. Muslim women in northern Nigeria recognized Islamic laws governing marriage, divorce, inheritance, child custody, and socialization in general. Women also, are being regarded as the "possession" of their fathers, not usually have the right to the freedom and must live in purdah. As such, the Nigerian Muslim women are among the most strictly secluded in Africa. ${ }^{11}$ In fact, a man's prowess and status in the region were measured according to the number of wives he had. However, Muslim women in northern Nigerian societies can be categorized by classes and communities for our purposes, the most relevant broad categories are only three: (a) women below the subsistence or poverty line; (b) women who move continuously between subsistence or poverty and often descend below the subsistence line with the disappearance of their means of earning a livelihood; and (c) women firmly above the poverty line. All these categories had an impact on Muslim women cultural, social, and economic life in northern Nigeria and, as such, also on the status and role of Nigerian Muslim women in northern Nigeria. In the south, the position and status of Muslim women were slightly different but not necessarily better. ${ }^{12}$

\section{The Status of Muslim Women in (northern) Nigeria: The Clear Example of Inequality}

Understanding the status of Nigerian Muslim women begins with the definition of the term. The term "status" is defined in a multiple ways but for our study, it denotes person's social, legal or professional position or rank in relation to others in a social system or sub-system which is also

\footnotetext{
${ }^{11}$ Bilkisu Yusuf 1988:1

12 Latifa Okunnu op cit.
} 
distinguishable from that of others through its rights and obligations. In Nigeria like the wider world, social status determines the rights advantages and roles of an individual. ${ }^{13}$ Each status position is expected in terms of a role. ${ }^{14}$ Since everyone occupies several distinct statuses within a society, he/she performs a variety of roles. It is imperative to make a distinction between the ideal role behavior, expected role behavior, and actual role behavior. ${ }^{15}$ The divergence between these leads to a change in the role perception of individuals. Status is realized through roles. This brings into focus the rights and opportunities provided to women by the State and socio-cultural institutions to perform these roles, which may not necessarily reinforce each other. ${ }^{16}$ The process of change is responsible for the divergence between the expected and the actual role behavior. ${ }^{17}$

Several decades ago, however, the status of women in Nigeria was not better than that of the west. She was not better than a slave. ${ }^{18}$ By logical implication, a woman cannot be equal to man since it is believed that women were created from man's ribs to help him what they called dependency syndrome. ${ }^{19}$ In fact, the Nigerian scenario today presents an interesting experience on the changing status of the woman. The history of the status and position of women in Nigeria dates to the pre-colonial era. Women at this period played their influential roles within their respective communities. $^{20}$ During the colonial period, the Indirect Rule System of administration disenfranchised many women except a few who rose in opposition to its challenge through the formation of Women's Leagues, or women groups, clubs, or unions to be enfranchised. ${ }^{21}$ Despite this position and status, they did not have the required support and encouragement.

It has been in the post-independence era that a more deliberate recognition is given to the important role of the woman in development. ${ }^{22}$ Interestingly, this measure of recognition has been

\footnotetext{
${ }^{13}$ Maryam Ibrahim, (45 years), Kano, interviewed on 11/03/2018.

${ }^{14} \mathrm{Ibid}$.

${ }^{15}$ Nana Auwalu, (34 years), Nguru, interviewed on 04/04/2018.

${ }^{16}$ Maryam Ibrahim, op cit.

${ }^{17}$ Nana Auwalu, op cit.

${ }^{18}$ Hajiya Hauwa, (41years), Nguru, interviewed on 24/03/2018.

${ }^{19} \mathrm{lbid}$.

${ }^{20}$ S. R. Janfa op cit.

${ }^{21} \mathrm{lbid}$.

${ }^{22} \mathrm{Ibid}$.
} 
more pronounced during military regimes than civilian, in involving women at the decisionmaking cadre of government. We can thus say the Nigeria woman has now moved away from the stage of agitating for equal rights because the laws of the land forbid discrimination against her. ${ }^{23}$ The government has equally remained instrumental in facilitating the formation of programmes that would enhance the socio-economic level of women. This has led to the formation of such institutions like the Women Education Model Centres, Better Life for Rural Women, Family Support Programmes (FSP) and the Family Economic Advancement Programme (FEAP). ${ }^{24}$

In the context of Northern Nigeria, the status of Muslim women was influenced by three main sets of factors: Nigerian law, societal law, and Islamic law. Firstly, the constitution of Nigeria does not tolerate discrimination based on sex, yet in a subtle way, it makes it difficult for a woman to achieve constitutional equality with the male. For instance, Section 39 of the 1979 Constitution of the Federal Republic of Nigeria guarantees full equality between men and women with regard to their rights, obligations, and benefits. ${ }^{25}$ While in reality, women could not enter into a contract without the consent of the written consent of her husband or relatives if she is not married. Women. Furthermore, when foreign women married to Nigerian men can become Nigerian citizens, foreign men married to Nigerian women cannot become citizens except by naturalization which can take up to 15 years. Another area in which the law discriminates against women in Nigeria is the requirement that women must obtain the permission of their husbands to get things like a passport visa, bank loan, birth control facilities, scholarship. ${ }^{26}$ In this context, we must seek gender equality before the law to improve the conditions and status of all women, as well as create an enabling environment for women to achieve these societal goals.

Secondly, Societal norms and values which involved the status of women in the social and cultural domains in northern Nigeria in the twentieth century were also enormous. Culture, for instance, which means the total way of life of the people as handed down to them by past

\footnotetext{
23 Ibid.

24 Ibid.

${ }^{25} 1979$ Constitution of the Federal Republic of Nigeria.

${ }^{26}$ Nana Auwalu, op cit.
} 
generations. ${ }^{27}$ This includes their practices, behavior, attitudes and their societal norms that they must accept. ${ }^{28}$ Yet it is sad to say that there are societal norms and attitudes in most cultures of northern Nigeria which have defied change or modification. ${ }^{29}$ A clear example of such diehard posture and rigidity is the place and status of women in society. Some of these common cultural assumptions about women are that a woman's place is the home and that she has "unique" and "specific" roles based on the biological imperatives of sex. Such roles in the traditional setting are not more than cooking and looking after children and the family. Other cultures hold that the woman is weaker than man and as such she is incapable of undertaking heavy responsibilities. ${ }^{30}$ Some traditions on the other believe the woman is less intelligent than the man hence she should not be given equal education with man; or that the woman is not expected to be in politics because "she should only be seen not heard". ${ }^{31}$ Because these norms or traditions have been passed on for many generations, they are accepted as 'normal' and no longer questioned. ${ }^{32}$ Therefore, to understand inhibitions on women development and progress, it is worthwhile addressing the myths about the status and position of women.

Thirdly, Islam, which is a complete way of life, has touched all aspects of women's status. Islam however, more than any other religion or polity, has a deep bearing on the role and status of women. In Islam, women are counterparts of men and endowed them with certain specific qualities that make it compulsory for both sexes to live together in a symbolic relationship. ${ }^{33}$ Now this going back to the Qur' an and Hadith has also a great importance in respect to the position and status of women in Islam. ${ }^{34}$ The man is not equal to the woman, neither is the woman equal to the man. Both must complement each other for the healthy growth of the society. The religion of Islam also provides several moral codes for men and women. In public life, the women expected to play a

\footnotetext{
27 S.R. Janfa op cit.

28 lbid.

29 Ibid.

${ }^{30}$ Ibid. 13

31 Ibid.

32 Ibid.

${ }^{33}$ Nana Auwalu op cit.

${ }^{34}$ Qur'an 9:71
} 
role and endure the hardship and sufferings of life as men. In short, all matters of life women are not different from men. They have equal opportunity and can share every aspect of religious virtues, except for those areas where sexual peculiarities matter. ${ }^{35}$ The Holy Prophet Muhammad encapsulated the importance of women when he says: "Heaven lies at the feet of the Mother" The importance, significance, and relevance of the mentioned statement brings out more than another thing the indispensability of women in the affairs of the world. Ibrahim N. Sada summarized the status of women in Islam in a very capsule form, when he said:

It is only in Islam that the status of woman as a full-fledged human being with independent legal status and independent rights and obligations is recognized...Islam treats a woman as a unique, autonomous, independent personality, who exists in her own right and who must, therefore, pursue the fulfillment of her life with a serious sense of personal responsibility. The woman must be defined in her own self, not as relative to man...From a material as well as a spiritual point of view, the woman's position and status are seen by Islam as the same and equal to that of a man. ${ }^{36}$

If we examine objectively, the teachings of the Qur'an and Hadith about women, we perceive immediately that the society in which we live today has departed extensively from both the letter and spirit of the Qur'an and Sunnah on the role and status of women. Despite all these rights and privileges are given to women by Islam, they were not even given equal or proper treatment with men in northern Nigeria. As many patterns of behavior and action are antithetic to the teaching of Islam, there seems to be a conflict of ideas arising from a mixture of different values and norms. ${ }^{37}$ The result is that some behavior associated with Islam in northern Nigeria have their origin either from Jahiliyya Arabs, pagan Berbers, or indigenous characteristics, mistakenly tagged on to Islam by the uninformed Islamic scholars. Many certain attitudes to women, for instance, are perpetuated for selfish reasons polygamy, rather than being an exception has become the role when in fact over $90 \%$ of the men who practice polygamy are ignorant of the

\footnotetext{
${ }^{35}$ Qur'an 4:1

${ }^{36}$ Ibrahim N. Sada op cit.

${ }^{37}$ Latifa Okunnu op cit.
} 
Amana (trust) they are entering. ${ }^{38}$ To them, it is a sign of affluence rather than a religious obligation. Consequently, they are not practicing it as the religion enjoins many go beyond the limit of four and on top of that indulge in adultery by harboring concubines outside the matrimonial homes.

\section{The blurred Boundary between Men and Women: The Major Obstacles to Changing Role of Muslim women in northern Nigeria}

Regarding male-female social and religious relationships in northern Nigeria, there are many areas in which northern Nigerian Muslim women's rights and status have been tempered, ignored and neglected in the name of either Islam or custom. I shall deal here with only a few.

\subsection{Subordination to male relatives}

In northern Nigeria settings, culture and man's formulated laws have deprived the womenfolk of enjoying their freedom. ${ }^{39}$ Descriptions of northern Nigerian urban society during the late nineteenth century usually portrayed women as being mostly confined to the home. These women were generally under the authority of one of their close male relatives: father, brother, or husband. ${ }^{40}$ The male guardians were the ones who usually made the decisions regarding the present and future of the women, and their authority extended to economic matters. ${ }^{41}$ The most significant realm in which women were allowed some economic power was regarding the dowry that they brought with them from their father's house. ${ }^{42}$ Inside the home, much reverence was shown to wives and mothers, and they played a dominant role in the running of the household. ${ }^{43}$ Ayesha Imam summed up the status of women within their family in northern Nigeria:

Most women also suffer from a double work load. After working all day on the farm, at the market, selling goods, weaving, threshing, pounding, grinding, or in the school, hospital, office or factory, they must still look after the

\footnotetext{
38 Ibid.

${ }^{39}$ Sadiya Adamu, (31 years), Sokoto, interviewed on 10/03/2018.

40 Hajiya Hauwa op cit.

${ }^{41}$ Sadiya Adamu op cit.

42 Hassana Bamadu, (46 years), Maiduguri, interviewed on 01/04/2018.

43 Hajiya Hauwa op cit.
} 
children, cook, clean the house and wait on the men-while men can relax and rest instead of also taking up their share of the domestic responsibilities. It is within the family that women's oppression is most clear. ${ }^{44}$

\subsection{Attitude toward children}

The status of northern Nigerian Muslim women can also be deduced from the attitude toward children in the family. Thus, for example, there were love and affection connected with the birth of boys, and especially the first-born ones, but there were no similar love and affection regarding the birth of girls. ${ }^{45}$ In comparing the position of sons and daughters in the family, it was noted that boys had more rights than girls. Thus, girls were protected, that is, they were usually kept at home, where they had numerous household tasks to perform. ${ }^{46}$ Although it is known that a growing number of Muslim girls went out to study and work, many still had to stay at home during the day or following their authorized absence. ${ }^{47}$

\subsection{Educational Factor}

Another aspect reflecting the status of northern Nigerian Muslim women, and influencing it, was education. Education should be an intrinsic part of any strategy to address the gender-based discrimination against women and girls that remains prevalent in our society because $\mathrm{it}^{48}$ helps women claim their rights and realize their potential in economic, political and social arenas. It is also the single most powerful way to lift people out of poverty. ${ }^{49}$ Yet, many people - especially women - are still excluded from education in Nigeria. ${ }^{50}$ Education of northern Nigerian Muslim women was also relegated to the background. ${ }^{51}$ Gender inequality in education is extreme. As Uzoma argues, the tradition, customs, socio-cultural values, ethics, motherhood instincts are some

\footnotetext{
${ }^{44}$ Ayesha Imam 1988:188

${ }^{45}$ Nana Auwalu op cit.

${ }^{46}$ Hassana Bamadu op cit.

47 Hajiya Hauwa op cit.

${ }^{48}$ Uzoma Aja-Okorie 2013:272.

49 Ibid.

50 Ibid.

${ }^{51}$ Latifa Okunnu op cit.
} 
of the factors influencing gender bias in the education sector. ${ }^{52}$ Oniye 2010 noted that the plight of women, in terms of education is compounded by this negative attitude of parents toward female education. ${ }^{53}$

The Nigerian educational system is in principle designed to serve girls and boys equally but Northern Nigeria is a religious and culturally dominated area where female seclusion is practiced, girls are less likely to access school, to remain in school or to achieve in education than boys. ${ }^{54}$ Girls were very rarely educated, academically speaking, until the last quarter of the nineteenth century, and this prevented their full participation in western education. ${ }^{55}$ The gender disparity is exacerbated by the powerful economic and social rationale for investing in the education of sons rather than daughters, as daughters are perceived to be less valuable once educated, and less likely to abide by the will of the father, brother or husband. ${ }^{56}$

The advocates of early marriage are informed by the religious perception of the position of women in the region. Therefore, many parents withdraw young girls from school into marriage for which they are not physically and mentally prepared. ${ }^{57}$ Many girls are married at an early age and against their wills. ${ }^{58}$ When they are divorced they often loose custody of the children they have suffered to bear and look after. Sometimes, even the knowledge of the fundamental of Islam is sometimes denied these girls before they are given out in marriage. ${ }^{59}$ There is a lot of social prejudice against female education and now that school fees have to be paid, girls from poor families stand very chance of going to school. Those that did not attend the western educational institutions have been abandoned and condemned to ignorance by no other than Islamic scholars. ${ }^{60}$

\subsection{Participation in Ceremonies}

\footnotetext{
52 Uzoma Aja-Okorie op cit, 275.

53 Oniye 2010 cited in Uzoma Aja-Okorie 2013:275.

54 Sarah Aguigwo 1998:52; Uzoma Aja-Okorie op cit, 273.

${ }^{55}$ Hassana Bamadu op cit.

${ }^{56}$ Uzoma Aja-Okorie op cit.

${ }^{57}$ Latifa Okunnu op cit.

58 Hassana Bamadu op cit.

${ }^{59}$ Latifa Okunnu op cit.

${ }^{60}$ M. Ladi Ayama 1988:13
} 
The status of northern Nigerian Muslim women can also be determined by their participation in ceremonies. Women had special roles in ceremonies connected with family life, but many of these events had men as their focus. ${ }^{61}$ Women could participate in almost all ceremonies in the societies. Even though there was special restricted custom related to the wedding, naming, festivities, and funeral procession but some were later abolished. For instance, most of the customs connected with the funeral ceremony drastically changed with the emergence of the Shi'a sect in 1979, now northern Nigerian Muslim women are clearly included. ${ }^{62}$ In one case, women can accompany corpse to the cemetery.

\subsection{Modesty and Public appearance}

Another aspect that reflected the status of northern Nigerian Muslim women was related to the code of modesty, much attention was paid to keeping proper morals, but punishment for their breach was much harsher for women than for men. Since women were usually kept at home, mainly in the earlier period and in urban areas, men did all the shopping in the market place, based on the regular needs of the family requirements specified by their wives. ${ }^{63}$ This was done to prevent any chance inter-gender meeting between non-relatives. Clothing customs of Muslim women in northern Nigeria reflected traditions, Muslim habits, and regional characteristics. For instance, almost all the northern Nigerian Muslim women, urban and rural married and unmarried women used to cover their hair in public with a scarf or headgear. ${ }^{64}$

\subsection{Economy Factor}

In traditional setting, economy is another area in which northern Nigerian Muslim women are marginalized. Under such dispensation and in recognition of the fact that northern Nigerian Muslim women have no ability to acquire and control the major factors of production such as land, labor, and capital. ${ }^{65}$ In most rural areas, the land is controlled by men: but those who work on the farms are women. For instance, the land was governed through native laws and custom with no

\footnotetext{
${ }^{61}$ Nana Auwalu op cit.

62 Hassana Bamadu op cit.

${ }^{63}$ Fati Usman, (32 years), Maiduguri, interviewed on 02/04/2018.

64 Nana Auwalu op cit.

65 Ibid.
} 
considerable place for women since they were generally viewed as producers, rearers of children and home makers. ${ }^{66}$ They were generally used as a source of cheap labor to increase the men's yields on the farms. Men's ability and capability were measured according to the number of wives they had, and these wives constituted the bulk of the unpaid laborers that enhanced the economic fortunes of the menfolk. They own no real income except money from sales of their farm produce which they use to supplement the family income and for their daughter's marriage. Some engage in hand crafts like pottery, local mat, fan, sponge, weaving, knitting etc. Others had a little hope where they were opportune to sell food items and other articles of trade at home or some of the major markets in the area. ${ }^{67}$

\subsection{Socio-Political Factor}

Social and cultural barriers to women leadership. This is still prevailing in northern Nigeria where many people are of the view that northern Nigeria is not socially and politically "ripe" enough to have women as head of family or governance. Indeed, in many of the northern Nigerian cultures and even religious women leadership may be termed as taboo and an insult to the men. However, women are among the poorest and so they cannot participate effectively in politics. ${ }^{68}$ Men discourage women from participating in politics, often taking advantage of women because of their petty jealousies and outburst of anger. ${ }^{69}$ Men operate on the principle of divide and rule. They do not enhance the virtues of women. ${ }^{70}$ Women are rarely consulted on issues, neither are they involved in decision making. ${ }^{71}$ During the election, her role was only to take orders and nothing else, even to the level of voting. She had no choice other than that of her husband. ${ }^{72}$

\section{Factors related to Changing Status of Northern Nigerian Muslim Women}

\footnotetext{
${ }^{66} \mathrm{Ibid}$.

${ }^{67} \mathrm{lbid}$.

${ }^{68}$ Uwa Lohor op cit, 41.

$69 \mathrm{lbid}$.

$70 \mathrm{lbid}$.

${ }^{71} \mathrm{lbid}$.

72 Hajiya Hauwa op cit.
} 
In northern Nigeria today, Muslim women in both rural and urban societies are beginning to rise up to their responsibilities in almost all spheres due to the number of changes which took place in the region. presents an interesting experience on the changing role of women. ${ }^{73}$ These changes in the status of northern Nigerian Muslim women in the late twentieth and beginning of twentieth-first centuries were deeply intertwined with the wider processes of changes that Nigeria experienced during that period, resulting from internal and external developments in the western world, Middle East and Africa. Northern Nigerian Muslim women are no longer, never been relegated to the kitchen, or home. They have various important roles in the political, religious, military, academics, business, bureaucracy, and social developments, and they have never failed to be the motherly bosoms for the liberation struggles in politics, ${ }^{74}$ and being reinvigorated for a stronger and more virile struggle. ${ }^{75}$ These rapid changes, whether we like it or not, not only in Nigeria but throughout the world. These changes took place because of some major factors identified which are:

\subsection{Colonialism and neo-colonialism}

Colonialism and neo-colonialism have brought the improved changing status of Muslim women in northern Nigeria. The so-called Industrial Revolution had improved the status of women because it had brought into existence large number of industrial complexes which demand for a large number of workers (women inclusive). It also brought about the revolt of western women, which later manifested in the women liberation movements. ${ }^{76}$ These developments ended the injustice, inequality, inequity, and oppressions against womenfolk and paved way for participation of women in nation-building. The Muslim women in northern Nigeria were so impressed with the women liberation movements success of the west that for them anything that emanates from there is exemplary. The Europeans' women socio-political systems and liberation movements were regarded as flawless and subject of diligent imitation. It is through the group with this mental

\footnotetext{
73 S. R. Janfa op cit, 12.

${ }^{74}$ Paulin Tare Shagaya op cit, 9.

75 Ibid.

${ }^{76}$ Ibrahim N. Sada op cit, 27
} 
attitude that women's liberation movement found its way to the northern Nigeria and drastically changed the role of Muslim women from home-based role to nation-building.

During the earlier period of colonialism of northern Nigeria, Muslim leaders and scholars responded in three ways. Some welcomed admired and imitated western and secular ways of life in all respect; others rejected, and the rest stood on the fence. One of the most important changes was brought by the British Colonial officers and their life style, which seemed to stop and endanger the Islamization and spread of Islamic culture in the region. It was considered to separate the indigenous culture from Islamic culture and infiltrated western culture. Although these contacts were limited in number, they were conducted by influential members of the growing westernized component of the community, whose importance increased further under British rule. With the arrival of the British colonialists, the Nigerian Muslim women changed their external focus of inspiration during the nineteenth and twentieth centuries and moved gradually from the Muslim realm. The acquisition of new ideas and customs depended on spiritual, physical, and socioeconomic factors, but not every Nigerian woman accepted all the innovations. Furthermore, those concepts regarding the status of women were among the ones that were the most difficult for many to adopt. Consequently, even though there were changes in the cultural, social, and economic behavior of the Nigerian Muslim women, these changes were slower to affect the status of the Nigerian Muslim women than that of Muslim men.

\subsection{Technological development and Western education}

The influence of ideas, concepts and way of life of the people of the technologically advanced countries. The European's food, dress, etiquettes, morals, laws and event their political and social systems were subject of emulation by the Muslim women in northern Nigeria. ${ }^{77}$ Muslim women in northern Nigeria have been looking more closely and objectively at the secular philosophy and ideas of the western world, more especially participation of women in politics and

\footnotetext{
${ }^{77}$ Zainab Bukar, (40 years), Maiduguri, interviewed on 06/04/2018.
} 
nation-building. Female students from northern Nigeria started to go to the West to study. ${ }^{78}$ Today, western education is crucial, and efforts made towards improvement of women's education is synonymous with that designed to improve the status of woman in northern Nigeria.

\subsection{The Women movements and organization}

The primary goal of exploring and implementing the ways and means of changing status of northern Nigerian Muslim women as well as their effective participation in the development process in Nigeria started very many years ago by forming women cooperative societies, organizations and associations. ${ }^{79}$ It is traceable to the colonial era when women in different parts of Nigeria consciously or unconsciously organized themselves into groups that made inputs into the system and governance at the time. For instance, there was Aba Women riot of 1929 which was an instance of cultural nationalism; an opposition to the introduction of oppressive colonial taxation and the protection of the moral foundations of the society. ${ }^{80}$ There were groups that concerned themselves with the provision of the necessities of life i.e. love, food, clothing, protection, etc. Yet, there those who whose influences were penetrating in the political and economic spheres. In whatever manner women and their groups activated themselves, the unwritten motive was empowerment. The success of the Aba Women riot/revolt marked the beginning of a long walk to women empowerment in Nigeria. ${ }^{81}$ By the mid-1950s, various women groups have begun to emerge in Nigeria. These organizations served either as pressure or interest groups. Some of them were the National Women Union (NWU) and the Federation of Women Societies (FWNS). By 1958, the National Council of Women Societies NCWS) was founded with the aim of bringing into being throughout Nigeria, a Federation of non-political Women Organizations to assist women in towns and villages in their important roles as home makers and nation builders. ${ }^{82}$ It seeks to create among its members an awareness of good citizenship. It is the

\footnotetext{
${ }^{78} \mathrm{lbid}$.

${ }^{79}$ Uwa Lohor op cit, 41.

${ }^{80}$ Ben Orewere op cit, 22.

$81 \mathrm{lbid}$.

$82 \mathrm{lbid}$.
} 
umbrella body of all women organizations in Nigeria. It has its headquarters at Abuja and a Liaison office in Lagos. There are state branches with headquarters in the state capital. ${ }^{83}$

Since the early eighties, however, new women groups have been emerging as a nongovernmental organization (NGO), many of them with varying motives. Some of the have been religious in nature and have been truly committed to development as well as upliftment of womenfolk generally ; some have sharply attracted attention to themselves, especially from government and for reasons other than the real interest of the majority of women while some few ones find the formation of NGO's an easy way of making quick money, again from government and other cross-national development. ${ }^{84}$ One of these women religious organizations is the Federation of Muslim Women's Associations in Nigeria (FOMWAN) which founded in 1985 and has been working to improve the status of Muslim women and children.

With the advent of Muslim women organizations, many northern Nigerian Muslim women and girls were exposed to a western form of education and in the process imbibed the changing status, roles and positions of Muslim women around the world. Gradually, with the increase efforts of the Muslim women organizations and movements, both girls and ladies began to take interest in their status, roles, positions, rights and privileges. It was on the solid foundation of Islamic brotherhood fostered and nurtured by this organization that many Islamic movements sprang up.

\subsection{Economy}

The economic factors had a strong impact on the changing status and position of Muslim women in northern Nigeria. Because of recruiting economic crises in the late nineteenth century, Muslim families became willing to allow women to work outside the home. ${ }^{85}$ Some families also allowed their daughters to pursue vocational training and thus exposed them also to academic studies, especially at schools operated on a western model. ${ }^{86}$ This trend clearly shows that when women were needed in the government or private syndicate they were encouraged to work.

\footnotetext{
$83 \mathrm{lbid}$.

${ }^{84} \mathrm{Ibid} 23$.

${ }^{85}$ Yani Garba, (28 years), Maiduguri, interviewed on 23/03/2018.

${ }^{86} \mathrm{Ibid}$.
} 
Economically, women are not only used as a reserve work force. They are also expected to succumb to radically changing fashions in dressing, make-up, etc. in order to stimulate domestic consumption in an economy built on the principle of unlimited growth. ${ }^{87}$

\subsection{Cultural tolerance}

Cultural tolerance has thus brought about a change which has opened up suitable avenues for participation in activities that have been the exclusive reserve of men. ${ }^{88}$ This development has brought about improved the status of women in the region, and of recent, led to increased involvement of women in almost all professions. ${ }^{89}$

\section{Beyond Men and Women Divide: The Changing status of Muslim women in northern Nigeria}

Today, northern Nigerian Muslim women have come a long way and excelled in almost every field of human endeavor in spite of a certain degree of religious, constitutional and cultural pressures to keep them down. They are filling their position as wives and partners rather than inferiors as a home marker and in other carriers and professions. Suffice to say that with steady transformation in the society due to the influences of education, social interaction, intermarriages, civilization and religion, the role of woman has significantly broadened. ${ }^{90}$ The social status of women has been lifted through education and hard work. Above all, women; who were previously seen as agents of procreation only have now taken up greater responsibilities, either as workers, business women or politicians. Professions that were culturally tagged as exclusively for men have been penetrated by women. ${ }^{91}$ However, the larger proportion is till disadvantaged politically, educationally, culturally and economically. On the economic arena, the woman is still used in farming, processing agricultural products, weaving, dyeing, mat-making and pottery including the usual housekeeping and childrearing activities. ${ }^{92}$ Despite this, the woman has remained the most

\footnotetext{
${ }^{87}$ Zara'u Hamisu, (48years), Abuja, interviewed on 02/03/2018

${ }^{88}$ S. R. Janfa 1998:15.

${ }^{89}$ S. R. Janfa 1998:15.

${ }^{90}$ S. R. Janfa 1998:15.

${ }^{91}$ S. R. Janfa 1998:15.

${ }^{92}$ S. R. Janfa 1998:15.
} 
potent agent of development, scaling through cultural barriers to integrate the norms of society with the challenging roles of development. ${ }^{93}$ There are many famous business women in the region like Hajiya Mariya Sanusi Dantata, Late Maryam Babangida.

Take the judiciary, for instance, we have northern Nigerian Muslim women heading the Justice Binta Murtala-Nyako, the Federal High Court judge. Zainab Adamu Bulkachuwa, OFR, she is a judge and president of the Nigerian courts of appeal. This is the first time. There are also northern Nigerian Muslim women judges and qadis. Even at the state level, there northern Nigerian Muslim women magistrates, chief magistrates, while northern Nigerian Muslim women lawyers are uncountable.

In the field of education, we have had northern Nigerian Muslim women professors. She is regarded as the first woman novelist from Northern Nigeria. Some of her writings are The Stillborn, Lagos: Longman (Drumbeats), 1984. The Virtuous Woman, Longman Nigeria, 1987. Cobwebs \& Other Stories, Lagos: Malthouse Press, 1997. The Descendants, Tamaza, 2005. The Initiates, 2007. There are also many northern Nigerian Muslim women as commissioners, education secretaries, supervisors and some are heading primary and post-primary institutions. Others are inspectors and directors of education.

In the field of sports and social development, northern Nigerian Muslim women have shown an amazing tenacity. Between the mid-eighties to date, the headship of the ministry responsible for sports has been dominated by women. A cursory look at the government parastatals shows northern Nigerian Muslim women have had a comparatively fair share in the federal level. And at the state level, there are also many ministries of sports and social development headed by northern Nigerian Muslim women.

The northern Nigerian Muslim women have also not been left on the political scene. Presently, no fewer than three ministries are headed by northern Nigerian Muslim women. The Nigerian Port Authority (NPA) is headed by Hadiza Bala Usman. The Nigerian Ministry of Finance is also chaired by Zainab Ahmed. Nigerian Ministry of Women affairs is headed by Hajiya

\footnotetext{
${ }^{93}$ S. R. Janfa 1998:15.
} 
Jummai Alhassan, to mention are a few. There are also many who are northern Nigerian Muslim women running the affairs of local government councils. The number of northern Nigerian Muslim women appointed as councilors are also quite impressive. Quite a number of them are also serving as council secretaries.

\section{Conclusion and Suggestions}

Although traces of records had shown that some northern Nigerian Muslim women in extreme cases had excelled in their endeavors, their impact could not be felt in a man-dominated northern Nigeria. The first thing for the Muslim women in northern Nigeria in twentieth-first century to do is to clear their mind of the idea that they have second-class political, social, spiritual, economic, cultural or intellectual status. However, because of the society's attitude towards women, their world is conditioned by the psychological and repressive do's and don'ts dictated by men. This leads to low self-esteem. To eradicate this, the woman has to develop a personal sense of high self-esteem and self-actualization. The Federal Government must create an enabling environment for the enforcement of the relevant laws that give equal rights to men and women. The northern Nigerian Muslim women should be given their societal, constitutional and religious rightful status and place in society. Equally important is the role of the husbands who need to give the women encouraging support to enable them to use their God-given talents for the deserved 


\section{Reference}

\section{Primary sources}

Maryam Ibrahim, (45 years), Kano, interviewed on 11/03/2018.

Sadiya Adamu, (31 years), Sokoto, interviewed on 10/03/2018.

Zara'u Hamisu, (48years), Abuja, interviewed on 02/03/2018.

Hajiya Hauwa, (41years), Nguru, interviewed on 24/03/2018.

Yani Garba, (28 years), Maiduguri, interviewed on 23/03/2018.

Umma Abdullahi, (23 years), Nguru, interviewed on 04/04/2018.

Nana Auwalu, (34 years), Nguru, interviewed on 04/04/2018.

Zainab Bukar, (40 years), Maiduguri, interviewed on 06/04/2018.

Hassana Bamadu, (46 years), Maiduguri, interviewed on 01/04/2018.

Fati Usman, (32 years), Maiduguri, interviewed on 02/04/2018.

\section{Secondary sources}

Aja-Okorie, Uzoma. "Women Education in Nigeria: Problems and Implications for Family Role and Stability”. In European Scientific Journal. (October 2013), edition vol.9, No.28.

Ayama, Ladi M. “Keynote Address”. In ed. Rahmatu Abdullahi. The Muslim Woman: Challenges of the 15 ${ }^{\text {th }}$ Hijra. Ilorin: Woye \& Sons (Nig.) Ltd., 1988.

Ayesha, Imam. “Women's Liberation: Myth or Reality?”. In ed. Rahmatu Abdullahi. The Muslim Woman: Challenges of the 15 th Hijra. Ilorin: Woye \& Sons (Nig.) Ltd., 1988.

Janfa, S. R. "Culture and the Development of Women” in Ben Orewere et'al eds. The Plateau State Woman: Yesterday, Today \& Tomorrow. Jos: Ehindero (Nig.) Limited, 1998.

Lohor, Uwa. "The Participation of Women in Politics and Development in Plateau State: A Practical Approach” in Ben Orewere et'al eds. The Plateau State Woman: Yesterday, Today \& Tomorrow. Jos: Ehindero (Nig.) Limited, 1998.

Orewere, Ben. "NCWS in Plateau State: So far, How Far" in Ben Orewere et'al eds. The Plateau State Woman: Yesterday, Today \& Tomorrow. Jos: Ehindero (Nig.) Limited, 1998. 
Okunnu, Latifa. "The Importance of Women Education to the Proper Growth of Islam”. In ed. Rahmatu Abdullahi. The Muslim Woman: Challenges of the $15^{\text {th }}$ Hijra. Ilorin: Woye \& Sons (Nig.) Ltd., 1988.

Sada, Ibrahim, N. "The Muslim Woman and Her Responsibilities”. In ed. Rahmatu Abdullahi. The Muslim Woman: Challenges of the 15 th Hijra. Ilorin: Woye \& Sons (Nig.) Ltd., 1988. Shagaya, Pauline Tare. "Keynote Address" in Ben Orewere et'al eds. The Plateau State Woman: Yesterday, Today \& Tomorrow. Jos: Ehindero (Nig.) Limited, 1998.

Tallen, Pauline K. "Women in Partisan Politics" in Ben Orewere et'al eds. The Plateau State Woman: Yesterday, Today \& Tomorrow. Jos: Ehindero (Nig.) Limited, 1998.

Yusuf, Bilkisu. “An Address to the Muslim Sisters”. In ed. Rahmatu Abdullahi. The Muslim Woman: Challenges of the 15 th Hijra. Ilorin: Woye \& Sons (Nig.) Ltd., 1988.

1979 Constitution of the Federal Republic of Nigeria. 